\title{
Bird collisions at an offshore platform in the North Sea
}

\author{
OMMO HÜPPOP, KATHRIN HÜPPOP, JOCHEN DIERSCHKE AND \\ REINHOLD HILL
}

\section{Electronic appendix}

\section{MATERIAL AND METHODS}

\section{Bird calls}

The systematic and continuous registration of bird calls at FINO 1 started on 12. March 2004 and ceased on 1. June 2007, interrupted only by a few short equipment malfunctions. The bird calls were recorded by a shotgun condenser microphone (Sennheiser ME67) at the working deck. Calls of single birds or groups of birds were automatically stored in subsequent files on a computer not before gaps between calls were longer than $1.5 \mathrm{~s}$ or the maximum file length of $5 \mathrm{~s}$ was reached. The detectability of bird calls may be influenced by noise (from wind, waves and rain), air humidity, temperature and pressure (Kinsler et al. 2000) at a hitherto unknown degree. Especial software was developed to minimize at least the effects of wind, waves and rain. For more details consult Hüppop and Hilgerloh (2012).

For each file the minimum number of birds per species calling was estimated. Consistent with other studies (e. g. Farnsworth et al. 2004, Hüppop and Hilgerloh 2012) we assume that songbirds will have been detected up to a few hundred meters. Since even a small passerine flying at $20 \mathrm{~km} / \mathrm{h}$ will pass through the area of the microphone within one minute, the audio file with the highest number of individual calls was chosen for the analysis of the corresponding minute. We finally used the hourly totals of all minute maxima (for details see Hüppop et al. 2012).

The resulting bird call intensities should be regarded as a relative measure rather than an absolute number of calling birds, since, for example, it cannot be excluded that individuals circulating around the platform were recorded more than once and, on the 
other hand, not all individuals necessarily call (for details see Hill and Hüppop 2008, Hüppop et al. 2012, Hüppop and Hilgerloh 2012).

\section{Weather data}

To evaluate the influence of weather on the collision risk of birds with offshore structures, different weather parameters were regarded. Since it was not possible to relate the corpses exclusively to the night prevailing the respective collection date we considered the weather conditions of a seven day period ending with the collection date.

Since there were no data of fog, precipitation, visibility and cloud cover and longer data gaps in other weather parameters from the unmanned platform itself we decided to use hourly data from the nearest offshore weather station of the German Weather Service at the island of Helgoland as a representative for the German Bight. From the platform additionally relative air humidity at $90 \mathrm{~m}$ a.s.1. was taken into account (provided by the Federal Maritime and Hydrographic Agency), since it is a fairly good proxy of visibility. During autumn migration relative humidity $\geq 95 \%$ coincides with fog, drizzle or rain in $94 \%$ of the observation hours offshore (Hüppop and Hilgerloh 2012).

For an evaluation of the large-scale weather situation in the presumed take-off areas of the migrants in southern Scandinavia and western Central Europe (Dierschke et al. 2011, Hüppop and Hüppop 2011) we consulted wind and cloud cover data from the NCEP-DOE Reanalysis-2 (www.cdc.noaa.gov/cdc/data.ncep.reanalysis2.html [accessed 10. April 2015], Kanamitsu et al. 2002). These data are classified into four categories, depending on the relative influence of observational and model data on the gridded variable (Kalnay et al. 1996). Wind data are classified as "A" which indicates that the analysis variable is strongly influenced by observed data, and hence they are in the most reliable class. Cloud data are only classified as "C". This indicates that there are no observations directly affecting the variable and that cloud data should be interpreted with caution. Hence, we used the NCEP-DOE Reanalysis-2 total cloud cover data only as a general descriptor of the overall situation in the presumed departure areas. 


\section{RESULTS AND DISCUSSION}

\section{Species}

Table A1. Species and their numbers of individuals, split for season and age, at FINO 1 from October 2003 to December 2007.

\begin{tabular}{|c|c|c|c|c|c|c|c|c|c|c|c|c|}
\hline \multirow[b]{2}{*}{ Species } & \multicolumn{4}{|c|}{ January to June } & \multicolumn{4}{|c|}{ July to December } & \multicolumn{4}{|c|}{ total year } \\
\hline & total & adult & $1^{\text {st }}$ year & indet. & total & adult & $1^{\text {st }}$ year & indet. & total & adult & $1^{\text {st }}$ year & indet. \\
\hline Wigeon Anas penelope & 0 & & & & 1 & & & 1 & 1 & & & 1 \\
\hline Water Rail Rallus aquaticus & 0 & & & & 1 & & 1 & & 1 & & 1 & \\
\hline Golden Plover Pluvialis apricaria & 2 & 2 & & & 0 & & & & 2 & 2 & & \\
\hline Unidentified snipe & 0 & & & & 1 & & & 1 & 1 & & & 1 \\
\hline Snipe Gallinago gallinago & 0 & & & & 1 & & & 1 & 1 & & & 1 \\
\hline Dunlin Calidris alpina & 1 & 1 & & & 1 & 1 & & & 2 & 2 & & \\
\hline Great Black-backed Gull Larus marinus & 0 & & & & 1 & & & 1 & 1 & & & 1 \\
\hline Lesser Black-backed Gull Larus fuscus & 0 & & & & 1 & 1 & & & 1 & 1 & & \\
\hline Unidentified gull Larus spec. & 0 & & & & 2 & & & 2 & 2 & & & 2 \\
\hline Feral Pigeon Columba livia f. domestica & 0 & & & & 4 & & & 4 & 4 & & & 4 \\
\hline Woodpigeon Columba palumbus & 1 & 1 & & & 0 & & & & 1 & 1 & & \\
\hline Skylark Alauda arvensis & 11 & 7 & 2 & 2 & 7 & 1 & 2 & 4 & 18 & 8 & 4 & 6 \\
\hline Swallow Hirundo rustica & 1 & 1 & & & 1 & 1 & & & 2 & 2 & & \\
\hline Wood Warbler Phylloscopus sibilatrix & 0 & & & & 1 & & & 1 & 1 & & & 1 \\
\hline Willow Warbler Phylloscopus trochilus & 3 & & & 3 & 1 & & & 1 & 4 & & & 4 \\
\hline Chiffchaff Phylloscopus collybita & 3 & & & 3 & 0 & & & & 3 & & & 3 \\
\hline Grasshopper Warbler Locustella naevia & 1 & & & 1 & 0 & & & & 1 & & & 1 \\
\hline Blackcap Sylvia atricapilla & 2 & & 1 & 1 & 3 & & & 3 & 5 & & 1 & 4 \\
\hline Starling Sturnus vulgaris & 33 & 25 & 3 & 5 & 36 & 13 & 9 & 14 & 69 & 38 & 12 & 19 \\
\hline Mistle Thrush Turdus viscivorus & 2 & 1 & & 1 & 0 & & & & 2 & 1 & & 1 \\
\hline Blackbird Turdus merula & 24 & 15 & 6 & 3 & 19 & 10 & 8 & 1 & 43 & 25 & 14 & 4 \\
\hline Fieldfare Turdus pilaris & 7 & 5 & 1 & 1 & 67 & 29 & 8 & 30 & 74 & 34 & 9 & 31 \\
\hline
\end{tabular}


Song Thrush Turdus philomelos Redwing Turdus iliacus

Unidentified thrush Turdus spec.

Pied Flycatcher Ficedula hypoleuca

Robin Erithacus rubecula

Unidentified redstart Phoenicurus spec.

Wheatear Oenanthe oenanthe

Meadow Pipit Anthus pratensis

Pied Wagtail Motacilla alba

Chaffinch Fringilla coelebs

Brambling Fringilla montifringilla

Siskin Carduelis spinus

Linnet Carduelis cannabina

Twite Carduelis flavirostris

Snow Bunting Plectrophenax nivalis

Reed Bunting Emberiza schoeniclus

Unidentified passerine

Unidentified species

Sum

No. of flights

\begin{tabular}{|c|c|c|c|c|c|c|c|c|c|c|c|}
\hline 23 & 12 & & 11 & 164 & 47 & 86 & 31 & 187 & 59 & 86 & 42 \\
\hline 37 & 14 & 14 & 9 & 220 & 69 & 106 & 45 & 257 & 83 & 120 & 54 \\
\hline 0 & & & & 17 & & & 17 & 17 & & & 17 \\
\hline 1 & 1 & & & 1 & & 1 & & 2 & 1 & 1 & \\
\hline 1 & 1 & & & 0 & & & & 1 & 1 & & \\
\hline 1 & & & 1 & 0 & & & & 1 & & & 1 \\
\hline 2 & 1 & & 1 & 0 & & & & 2 & 1 & & 1 \\
\hline 2 & & & 2 & 9 & & 1 & 8 & 11 & & 1 & 10 \\
\hline 1 & & 1 & & 0 & & & & 1 & & 1 & \\
\hline 1 & 1 & & & 4 & & & 4 & 5 & 1 & & 4 \\
\hline 1 & & & 1 & 5 & 1 & 2 & 2 & 6 & 1 & 2 & 3 \\
\hline 0 & & & & 1 & & & 1 & 1 & & & 1 \\
\hline 0 & & & & 1 & & & 1 & 1 & & & 1 \\
\hline 0 & & & & 1 & & & 1 & 1 & & & 1 \\
\hline 1 & & 1 & & 2 & & 1 & 1 & 3 & & 2 & 1 \\
\hline 3 & 2 & & 1 & 1 & & & 1 & 4 & 2 & & 2 \\
\hline 1 & & & 1 & 6 & & & 6 & 7 & & & 7 \\
\hline 0 & & & & 21 & & & 21 & 21 & & & 21 \\
\hline 166 & 90 & 29 & 47 & 601 & 173 & 225 & 203 & 767 & 263 & 254 & 250 \\
\hline 98 & & & & 62 & & & & 160 & & & \\
\hline
\end{tabular}




\section{Injuries}
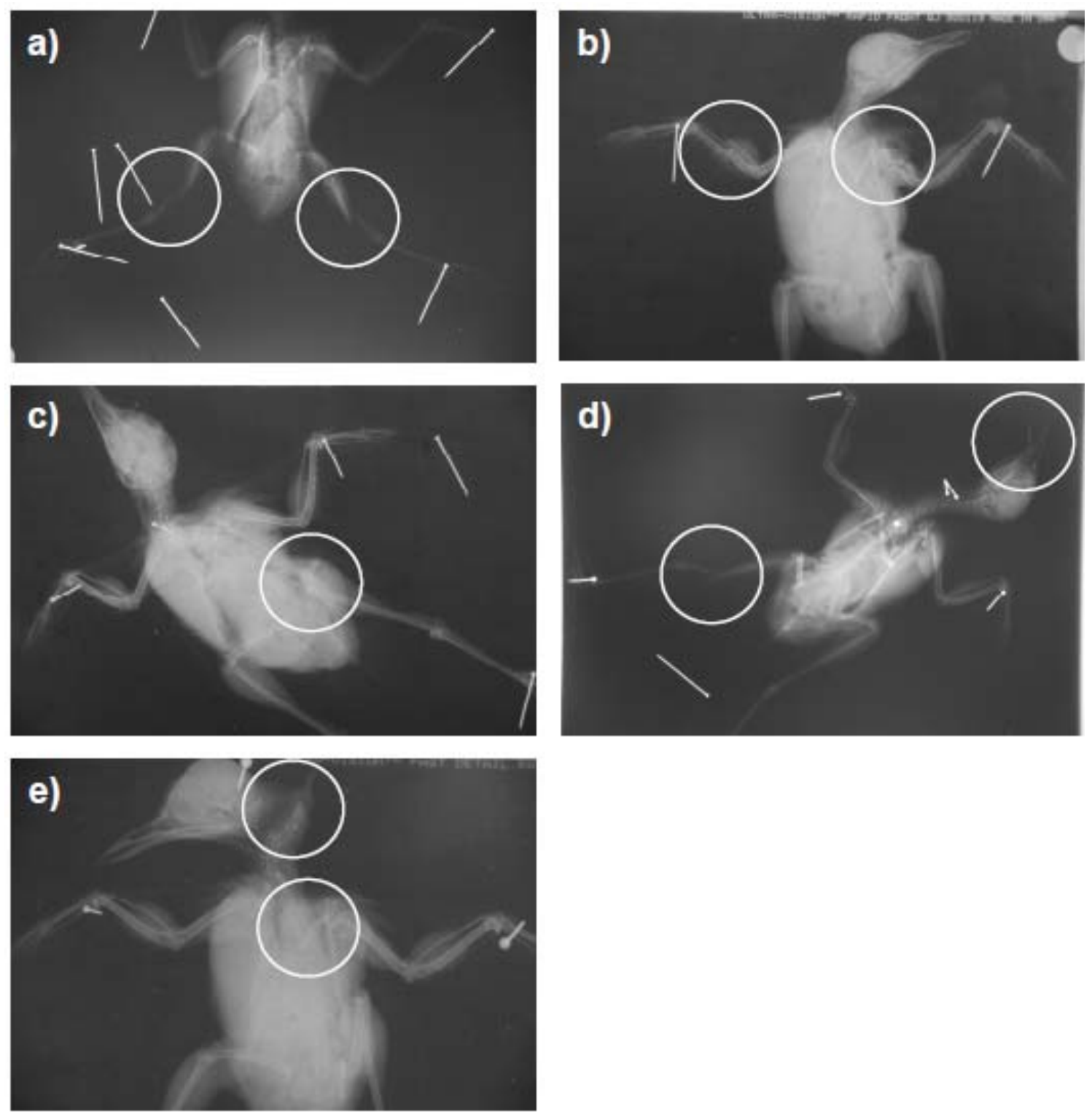

Figure A1. X-ray images of injured birds at FINO 1. A) Redwing Turdus iliacus with fractures in both femurs, B) Redwing with fractures of ulna and radius in one wing and of the humerus in the other wing, C) Song Thrush Turdus philomelos with a fractured femur, D) Song Thrush with a broken lower mandible and a fracture in one femur, E) Redwing with a divulsed head and a broken furcula. White circles indicate the mentioned injuries, but fixation pins do not. 


\section{Collisions and weather}

The weather conditions going along with collision events (e. g. rain, poor visibility and unfavourable wind directions and speeds or any combination of these) were rather different from case to case. The weather conditions at the platform not stringently lead to bird collisions: simply, only if conditions in the departure areas are favourable (preferably no rain, clear sky and weak or tailwinds, Richardson 1978, 1990, Alerstam 1990, Schaub et al. 2004) birds are inclined to migrate, cross the sea and occur in the area of investigation.

The weather conditions (and the bird call intensities) accompanying the three collision events with more than 50 carcasses and one event with few carcasses but special weather conditions give an impression of the complexity of the weather conditions leading to collision events and to figure out some general "rules".

29. October 2004: At this visit the highest number of corpses was found ( $n=199$ with 97\% thrushes, Fig. A2). Since the last visit to the platform was two days before, it can be ascertained that all these birds reached the platform within the preceding 48 hours. Bird calls indicated high numbers of birds close to the platform during the night/morning and again the evening/night hours of the 28./29. October (also mainly thrushes: $92 \%$ of all calls).

In the presumed south Scandinavian or north German (Schleswig-Holstein) departure areas a period of unfavourable headwinds for birds directing to SW since the 20 . October was interrupted by a short phase of weak winds with variable directions from the evening of the 23. October until the evening of the 24. October, coinciding with a few recorded bird calls in both nights, before winds were unfavourable again until midday of the 26 . October. Then again a few bird calls indicated activity in the following night. Advantageous conditions (weak or tailwinds and few clouds) over vast parts of the presumed departure areas lasted until the morning of the 28. October, but birds taking off SW-wards within this period were soon confronted with increasingly unfavourable crosswinds - in high altitudes even more than in lower ones - and with NE-wards moving dense clouds when passing the German Bight. There, in detail, humidity at FINO 1 increased to values over 95\% (since 5:40 hours CET), implicating poor visibility. This is confirmed by visibility data from Helgoland where it became totally clouded and rained in the morning hours. Finally, very high call intensity with up 
to 257 calls per hour was recorded at the platform, implicating a high collision risk (Hüppop and Hilgerloh 2012).
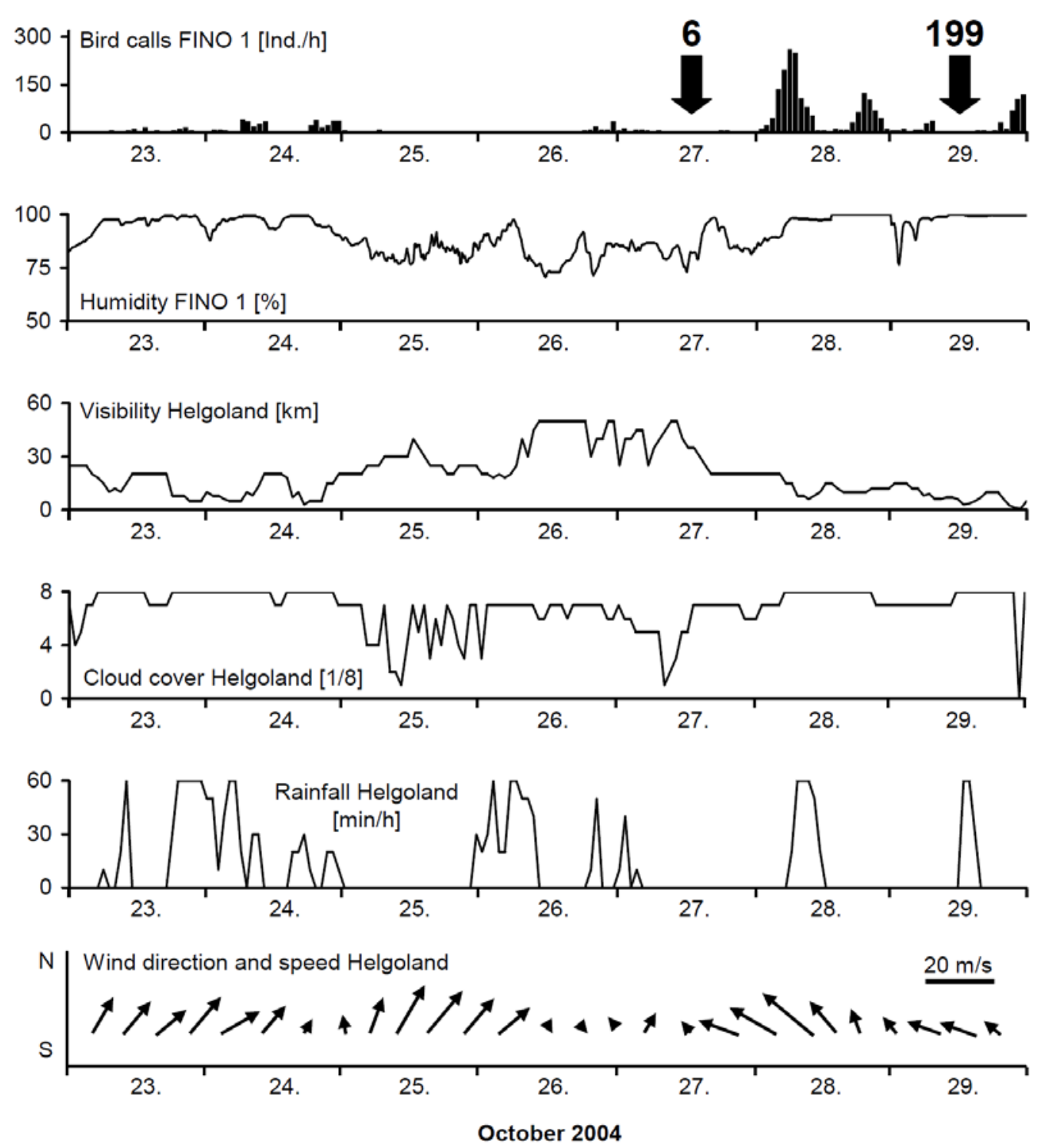

Figure A2. Carcasses (the digits indicate the numbers and the arrows the collection dates), bird calls and humidity at FINO 1 and weather parameters at Helgoland from 23. October to 29. October2004.

Also the situation in the evening hours of 28 . October implies a high collision risk. High call numbers up to 118 calls per hour go along with good wind conditions in the likely nearby departure areas at the Danish/German North Sea coast south of the NE-moving dense cloud cover but with very low visibility above the German Bight, locally expressed by $100 \%$ humidity at FINO 1 (perhaps fog) and by low visibility and dense 
cloud cover at Helgoland. Subsequent low call numbers (and presumably few collisions) in the first hours of the 29. October are accompanied by temporary better sight conditions.

29. November 2006: On this date the high number of 127 corpses $(80 \%$ thrushes, $19 \%$ Starling) coincides with a high intensity of bird calls with up to 259 calls per hour near the platform in the foregoing night (100\% thrushes, Fig. A3).

The weather conditions were quite different from those in the event described above. The whole week before the visit was characterised by strong southerly to westerly winds presumably preventing bird migration over the German Bight. In short periods with slight reductions of wind speed during the nights of 24./25. November, 26./27. November and 27./28. November and little cloud cover birds obviously tried to migrate as reflected by a few calls at FINO 1 . In the evening before the visit the wind situation was similar or even better. But later in the night the local conditions, a humidity of almost $100 \%$ at FINO 1 and low visibility combined with closed cloud cover and rain at Helgoland, became unfavourable. Obviously, in this night migrating birds, at least locally, were forced to fly in low heights which went along with extraordinary high call numbers and numerous collisions at the platform.

Although we actually do not know where the birds came from, we assume tailwind assisted reverse migration from SW to NE, possibly throughout the whole week before the visit. Especially the weather chart from 29. November at 00:00 hours GMT with southerly winds produced by a high pressure to the east and/or a low pressure to the west (e. g. http://www.wetterzentrale.de/archive/2006/brack/bracka20061129.gif [accessed 10. April 2015]) perfectly conforms to the situation typical for autumn reverse migration (Richardson 1978). Indeed, nocturnal passerines have been observed to perform short flights at least over land with headwind components of more than $10 \mathrm{~m} / \mathrm{s}$ (Karlsson et al. 2011). However, the wind conditions in this night were not suited for long flights across the sea in the preferred SW-direction. Under such strong headwinds it is impossible that the calls registered in large numbers already in the early evening hours are from birds which departed after sunset, such as thrushes, from the northeastern coasts of the German Bight with SW-orientation. Rather, birds which departed from the south-western coast of the German Bight in reverse direction (NE) with a 
flight speed of about $12 \mathrm{~m} / \mathrm{s}$ in air (Bruderer and Boldt 2001) could easily have reached the platform within an hour assisted by the south-westerly tailwinds of $10 \mathrm{~m} / \mathrm{s}$.
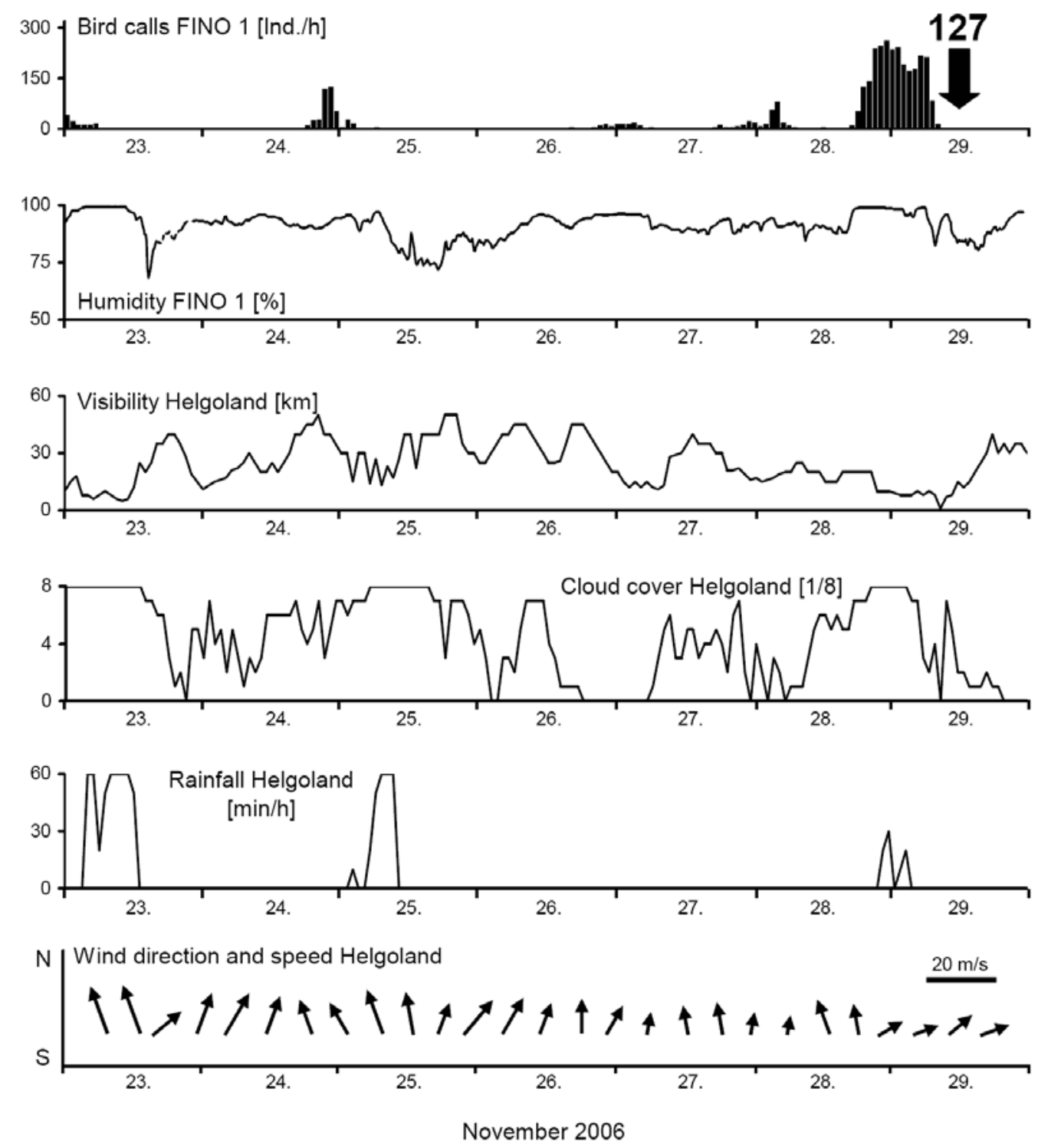

Figure A3. Carcasses (the digit indicates the number and the arrow the collection date), bird calls and humidity at FINO 1 and weather parameters at Helgoland from 23. November to 29. November 2006.

1. October 2003: On this very first visit to the platform 89 carcasses $(97 \%$ Song Thrushes, 3\% other species) were collected (Fig. A4). Recently, Aumüller et al. (2011) have shown that even three days after a mass collision night numerous carcasses remain (winds were very weak and gulls absent from the platform during this period). 
Therefore, we can assume that the low wind speeds from 26. September to 29. September inhibited that corpses were blown away. Rather the corpses found on 1. October were accumulated from collision events during the repeatedly unfavourable migration conditions up to the collection date.

Since the technical equipment was not yet fully established we cannot consult contemporary weather and call intensity data from FINO 1. However, for the late night hours of 28./29. September and the morning hours of 29. September the local weather data from Helgoland imply unfavourable flight conditions as expressed by low visibility combined with closed cloud cover and rain, although moderate tailwinds above the German Bight should have supported migration to SW. Low wind speed and moderate total cloud cover of not more than $30 \%$ in the presumed south Scandinavian or north German (Schleswig-Holstein) departure areas gave the preconditions for this collision event.
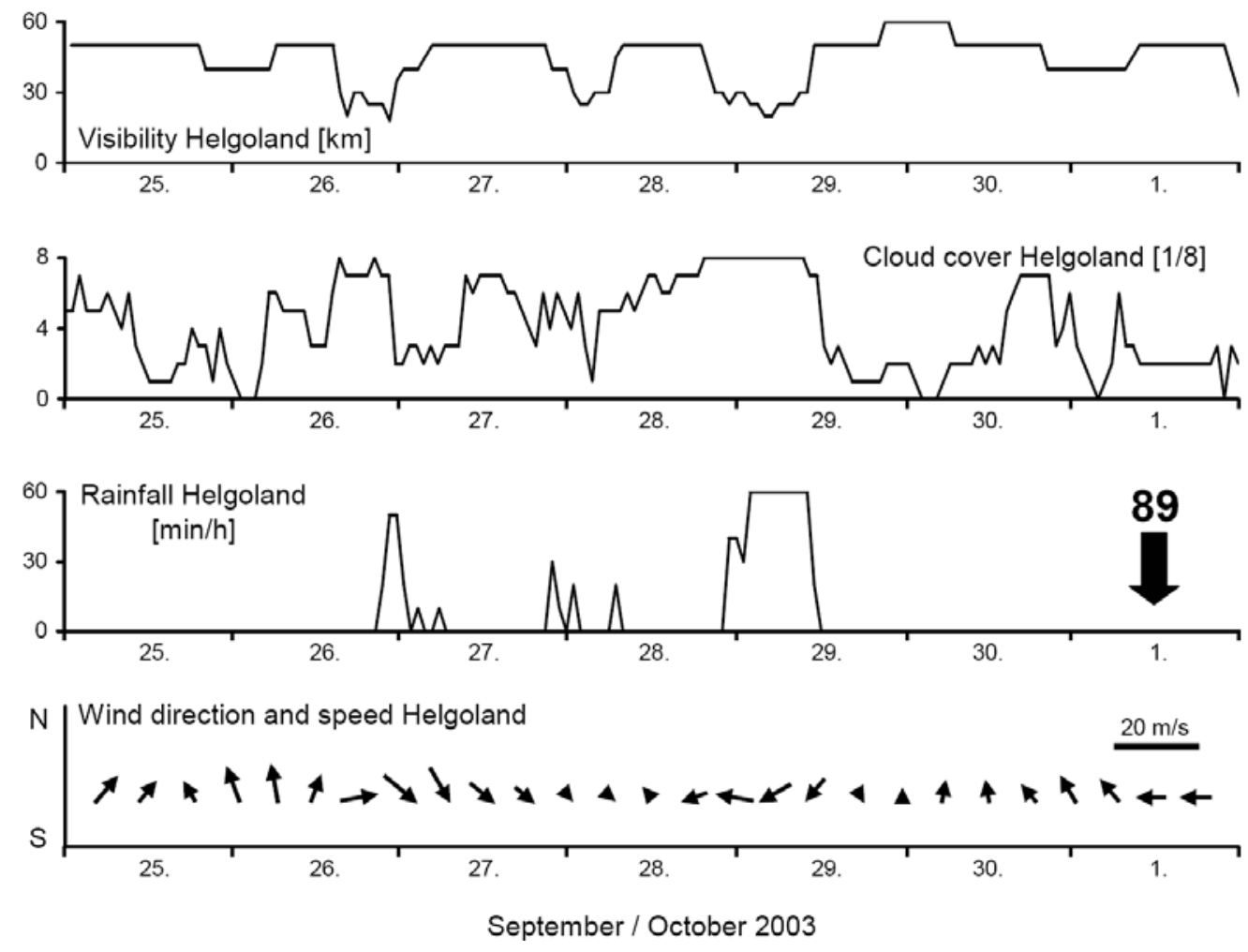

Figure A4. Carcasses (the digit indicates the number and the arrow the collection date) at FINO 1 and weather parameters at Helgoland from 25. September to 1. October 2004. 
All events described so far were characterized by winds with a southerly component which ensures that a larger proportion of the corpses could be found on the platform (see below). Winds from other directions, including favourable tailwinds during autumn migration, will result in much higher proportions displaced into the sea. Actually there were several nights with high call intensity but few carcasses found thereafter as, for example, the following one.

10. November 2004: On this date only five carcasses were collected although there was "perfect collision weather" (Fig. A5), and high calling intensity with up to 132 calls per hour ( $94 \%$ thrushes) from the afternoon of the 9 . November until the morning of the 10. November was recorded accordingly.

Wind conditions in the presumed south Scandinavian or north German (SchleswigHolstein) departure areas were unfavourable until the evening of the 6. November. Then, wind speed and direction favoured departure for south-westward migration until the collection date as reflected by flight calls recorded within the following nights, interrupted only by a couple of hours with moderate headwinds in the night of 8./9. November. Cloud cover varied a lot but there were always departure areas with few clouds. In the night of 7./8. November most likely many birds were attracted by the illuminated platform because of unfavourable local conditions in the German Bight (low visibility, high cloud cover and rain) resulting in high call intensity and probably collisions.

Again in the night before the visit to the platform good departure conditions, i. e. little cloud cover in vast areas of south Scandinavia and northern Germany and favourable tailwinds, favoured intensive migration. Later in the night the departure conditions rapidly deteriorated. When reaching the German Bight - whilst wind speed and direction were still favourable - migrants were confronted with bad local weather conditions that were high humidity at FINO 1, and low visibility and closed cloud cover combined with rain at Helgoland. 

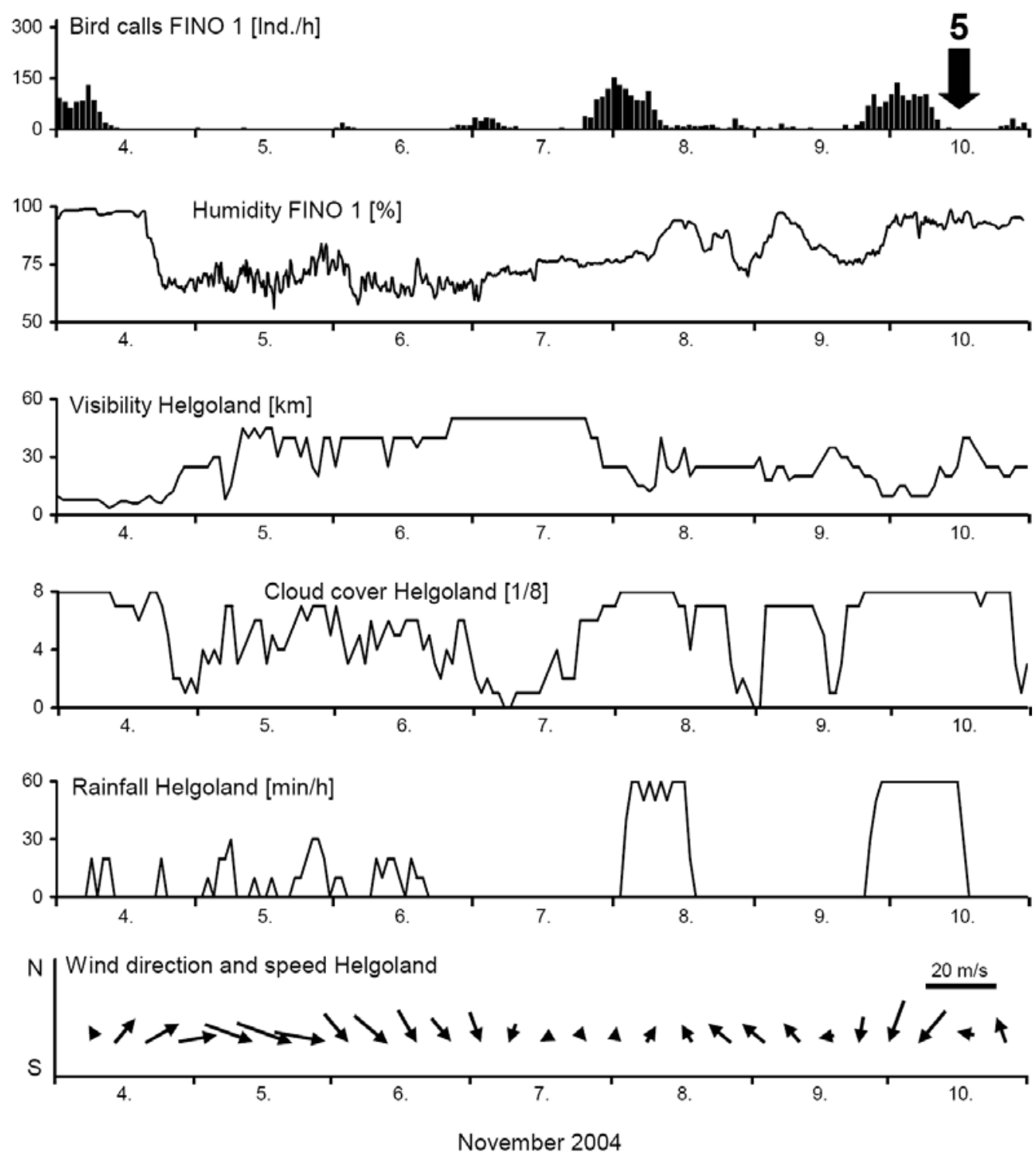

Figure A5. Carcasses (the digit indicates the number and the arrow the collection date), bird calls and humidity at FINO 1 and weather parameters at Helgoland from 4. November to 10. November 2004.

\section{REFERENCES}

Alerstam, T. 1990. Bird migration. Cambridge University Press, Cambridge, New York, Melbourne.

Aumüller, R., Boos, K., Freienstein, S., Hill, K. \& Hill, R. 2011. Beschreibung eines Vogelschlagereignisses und seiner Ursachen an einer Forschungsplattform in der Deutschen Bucht. Vogelwarte 49: 9-16.

BirdLife International 2004. Birds in Europe: population estimates, trends and conservation status. BirdLife International, Cambridge, UK. 
Blasius, R. 1894. Vogelleben an den deutschen Leuchtthürmen. Ornis 8: 577-620.

Bruderer, B. \& Boldt, A. 2001. Flight characteristics of birds: I. radar measurements of speeds. Ibis 143: $178-204$

Dierschke, J., Dierschke, V., Hüppop, K., Hüppop, O. \& Jachmann, K.F. 2011. Die Vogelwelt der Insel Helgoland. OAG Helgoland, Helgoland.

Farnsworth, A., Gauthreaux, S.A. \& Blaricom, D.V. 2004. A comparison of nocturnal call counts of migrating birds and reflectivity measurements on Doppler radar. J. Avian Biol. 35: 365-369.

Farnsworth, A. \& Russell, R.W. 2007. Monitoring flight calls of migrating birds from an oil platform in the northern Gulf of Mexico. J. Field Ornithol. 78: 279-289.

Hansen, L. 1954. Birds killed at lights in Denmark 1886-1939. Videnskabelige Medd. Dansk Naturhist. Foren. København 116: 269-368.

Hill, R. \& Hüppop, O. 2008. Birds and bats: automatic recording of flight calls and their value for the study of migration. BfN-Skripten 234: 135-141.

Hüppop, K., Dierschke, J., Hill, R. \& Hüppop, O. 2012. Jahres- und tageszeitliche Phänologie der Vogelrufaktivität über der Deutschen Bucht. Vogelwarte 50: 87-108.

Hüppop, O. \& Hilgerloh, G. 2012. Flight call rates of migrating thrushes: effects of wind conditions, humidity and time of day at an illuminated offshore platform. J. Avian Biol. 43: 85-90.

Hüppop, О. \& Hüppop, K. 2011. Bird migration on Helgoland: the yield from 100 years of research. J. Ornithol. 152: S25-S40.

Kalnay, E., Kanamitsu, M., Kistler, R., Collins, W., Deaven, D., Gandin, L., Iredell, M., Saha, S., White, G., Woollen, J., Zhu, Y., Leetmaa, A. \& Reynolds, R. 1996. The NCEP/NCAR 40-year reanalysis project. Bull. Am. Meteor. Soc. 77: 437-470.

Kanamitsu, M., Ebisuzaki, W., Woollen, J., Yang, S.-K., Hnilo, J.J., Fiorino, M. \& Potter, G.L. 2002. NCEP-DOE AMIP-II Reanalysis (R-2). Bull. Am. Meteor. Soc. 83: 1631-1643.

Karlsson, H., Nilsson, C., Bäckmann, J. \& Alerstam, T. 2011. Nocturnal passerine migration without tailwind assistance. Ibis 153: 485-493.

Kinsler, L.E., Frey, A.R., Coppens, A.B. \& Sanders, J.V. 2000. Fundamentals of Acoustics. John Wiley and Sons, New York.

Müller, H.H. 1981. Vogelschlag in einer starken Zugnacht auf der Offshore-Forschungsplattform „Nordsee“ im Oktober 1979. Seevögel 2: 33-37.

Richardson, W.J. 1978. Timing and amount of bird migration in relation to weather: a review. Oikos 30: 224-272

Schaub, M., Liechti, F. \& Jenni, L. 2004. Departure of migrating European Robins, Erithacus rubecula, from a stopover site in relation to wind and rain. Anim. Behav. 67: 229-237. 